\title{
EKSPLORASI PERILAKU INVESTOR INDIVIDU DALAM PENGAMBILAN KEPUTUSAN INVESTASI SUATU PENDEKATAN FENOMENOLOGI
}

\author{
Yudi Akhmd Sadeli1*1, Amiruddin², Darmawati ${ }^{3}$ \\ STIEM Bongaya; Makassar ${ }^{1}$ \\ Universitas Hasanuddin, Makassar ${ }^{2,3}$ \\ e-mail : yudi.akhmad.sadeli@stiem-bongaya.ac.id ${ }^{1}, \underline{\text { amircici@ yahoo.com }^{2}}$, darmajuanda03@gmail.com ${ }^{3}$
}

\begin{abstract}
Abstrak
Tujuan penelitian ini adalah untuk melihat bagaimana perilaku investor individu dalam menentukan keputusan investasinya. Perilaku investor memiliki peran penting dalam pengambilan keputusan investasi di pasar modal karena sebuah keputusan investasi yang tepat tidak hanya didasarkan pada faktor fundamental dan tehnikal belaka sebagai aspek rasional, tetapi dipengaruhi juga oleh faktor psikologis, yaitu perilaku investor yang merupakan aspek irasional dalam perdagangan saham. Penelitian ini merupakan penelitian kualitatif dengan pendekatan fenomenologi menggunakan paradigma interpretif. Metode fenomenologi yang dipakai adalah fenomenogi dari Schutz, yaitu suatu metode fenomenologi yang digunakan untuk memaknai perilaku investor berdasarkan motif yang ada pada mereka. Dililhat dari kelompok kepribadian investor maka urutan kelompok kepribadian investor terdiri dari Individulist, adventure dan guardian, sedangkan kelompok perilaku celebrity belum ditemukan. Pengetahuan yang baik tentang investasi dan pengendalian emosi serta belajar dari pengalamaan merupakan faktor-faktor yang menentukan perilaku investor dalam transaksi saham. Memahami investasi dan mekanisme perdagangan serta terus belajar dari sumber manapun merupakan modal dasar yang permanen yang perlu dimiliki investor disamping terus mengamati dan menyikapi isu-isu ekonomi yang berkembang.
\end{abstract}

Kata kunci : investor, individu, perilaku, saham, keputusan

Abstract
This study aims to see how individual investors' behavior is determining their investment decisions. Investor behavior has a vital role in making investment decisions in the capital market because an appropriate investment decision is based not only on mere fundamental factors as rational aspects but also by psychological factors, namely investor behavior, which is an irrational aspect in stock trading. This research is qualitative research with a phenomenological approach using an interpretive paradigm. The phenomenological method used is the phenomenology of Schutz, a phenomenological method used to interpret the behavior of investors based on their motives. Judging from the investor personality group, the order of investor personality group consists of Individualist, Adventurer, and Guardian, while the Celebrity behavior group has not been found. Good knowledge about investment and emotional control and learning from experience are factors that determine investor behavior in stock transactions. Understanding investment and trading mechanisms and continuing to learn from any source is a permanent primary capital that investors need to have and continue observing and responding to developing economic issues.

Keywords : individual investors; behavior; stock; decision

\section{PENDAHULUAN}

Di pasar saham, investor individu menunjukkan berbagai jenis perilaku. Teori keuangan tradisional (misalnya, prinsip arbitrase Miller dan Modigliani; prinsip portofolio Markowitz; teori penetapan harga aset modal Sharpe, Lintner dan Black; dan 


\section{AkMen

teori penetapan harga opsi Black, Scholes dan Merton) didasarkan pada asumsi bahwa investor individu mampu membuat keputusan keuangan yang sepenuhnya rasional dan merupakan pemaksimal kekayaan. Teori pasar efisien, yang didefinisikan oleh Fama pada tahun 1970, menyatakan bahwa dalam pasar yang efisien, investor cenderung bertindak rasional, dan harga saham menggabungkan dan menggambarka semua informasi yang tersedia. Selain itu, teori utilitas yang diharapkan berpendapat bahwa pembuat keputusan menganalisis semua alternatif yang tersedia berdasarkan utilitas mereka dan risiko yang terkait dan memilih keputusan yang optimal. Namun, investor individu tidak selalu membuat keputusan mereka hanya berdasarkan alasan dan logika tertentu; mereka didorong oleh emosi dan faktor psikologis

Investasi pasar modal selalu menjadi topik menarik untuk dibahas. Investasi serta pasar modal sudah menjadi salah satu pondasi dalam perekonomian suatu negara manapun. Indonesia mulai menunjukkan posisinya di dunia investasi pasar modal sebagai salah satu negara yang patut diperhitungkan. Peningkatan perdagangan saham di lantai bursa terus meningkat yang disusul dengan kenaikan jumlah investor.

Data BEI pada Januari 2021 memperlihatkan rata-rata nilai transaksi harian sebesar Rp. 20,5 trilliun. Dari nilai ini diketahui bahwa 69,5\% berasal dari investor domestic retail, $13 \%$ di dominasi oleh investor domestik institusi, dan sisanya sebesar 17,5\% berasal dari investor asing (Investasi Kontan.co.id, 2021). Besarnya peran dari investor retail ini karena didukung adanya solusi digital yang memudahkan mereka dalam berinvesatasi

Untuk meningkatkan jumlah investor pribadi di pasar efek Indonesia pemerintah melalui bursa efek Indonesia telah membuat suatu kebijakan yang disebut single investor identification (SID). Secara umum fungsi dari SID sama dengan eKTP yaitu berisi data tunggal investor. Dengan adanya SID ini maka investor akan terhindar dari manipulasi yang terkadang dilakukan oleh perusahaan sekuritas. Dengan demikian keamanan dari portofolio investor sangat terjamin.

Sangat penting memahami motivasi investor individu, pola pemikiran mereka, dan bagaimana gaya perilaku mereka dalam menentukan keputusan investasinya. Penelitian yang dilakukan oleh (Morrin et al. dalam Johnson et al, 2005) dan (Chan et al., dalam Wood dan Zaichkowsky, 2004) membahas mengenai bagaimana prilaku broker saham dan bagaimana investor individu memilih perusahaan yang akan dibeli sahamnya. (Wood dan Zaichkowsky, 2004) kemudian menyatakan bahwa penelitian seperti ini, yaitu membuat profil perilaku investor individu berkaitan dengan pemanfaatan informasi pasar dan bagaimana mereka bertransaksi akan dapat membantu perusahaan sekuritas dalam memetakan rencana promosi dan komunikasi mereka pada investor individu.

Keputusan investasi yang dilalukan oleh investor bukanlah hal yang mudah, namun harus dilakukan dengan perhitungan, pertimbangan dan analisa yang matang. Bagaimanakah proses yang dilalui investor individu sebelum mengambil keputusan investasi mereka? Apakah dalam pengambilan keputusan mereka telah didasarkan atas pemahaman teori-teori berinvestasi? Apakah mereka telah mengaplikasikan data-data akuntansi dalam penentuan keputusan?

Sebuah penelitian yang pernah dilakukan sebelumnya memberikan hasil bahwa keputusan berinvestasi investor institusional memanfaatkan informasi dari laporan akuntansi (Cecilia Natapura, 2009). Hal yang sama juga terjadi pada investor yang berasal dari negara lain yang menanamkan dananya di BEI mereka juga menggunakan informasi akuntansi dalam keputusan mereka berinvestasi (Rudi Chandra, 2010). Investor saham 


\section{AkMen \\ Volume 18 Nomor 3 Desember 2021 \\ Hal. 279 - 289 \\ e-ISSN : 2621-4377 \& p-ISSN : 1829-8524 \\ Hbmepage: https//e-jurnal.nobel.ac.id/index.php/akmen}

individu menurut (Tourani-Rad dan Kirkby, 2005) dalam (Kumar, Goyal 2019) bahwa investor individu tidak selalu menggunakan alasan dan logika tertentu dalam pengambilan keputusannya namun mereka digerakkan oleh faktor emosional dan psikologis.

Menurut (Scott, 2009), penekanan konsep teori kegunaan keputusan informasi akuntansi (decision usefulness of accounting information) adalah pada bagaimana laporan keuangan dapat lebih memberi manfaat. Konsekuensinya adalah informasi yang terdapat dalam laporan keuangan harus dapat memberi manfaat (useful) pada para pihak yang membutuhkan (users) berkaitan dengan decision making. Konsep keterkaitan nilai data akuntansi memberikan uraian tentang reaksi investor dalam menanggapi pengumuman laporan keuangan. Respon ini sebagai bukti pentingnya informasi yang terdapat dalam laporan keuangan yang kemudian dapat digunakan sebagai media bagi investor menentukan keputusan investasinya. Dengan demikian dapat dikatakan bahwa data akuntansi bermanfaat (useful) bagi investor

Penelitian ini akan melihat bagaimana perilaku investor individu dalam menentukan keputusan investasinya. Perilaku investor memiliki peran penting berkaitan dengan keputusan investasinya di pasar modal karena sebuah keputusan investasi yang tepat tidak hanya didasarkan pada faktor fundamental dan tehnikal belaka sebagai aspek rasional, tetapi dipengaruhi juga oleh faktor psikologis, yaitu perilaku investor yang merupakan aspek irasional dalam perdagangan saham. (Bayu Aprillianto, 2014) menyatakan bahwa perilaku investor di pasar modal yang umumnya mengambil keputusan investasi diantara satu investor dengan investor lainnya berbeda, meskipun kadang kala jenis investasi yang dipilih identik dan memiliki sumber informasi sama. Keputusan investor di antara pilihan investasi yang berbeda didasarkan pada faktor ekonomi serta faktor perilaku. Faktor perilaku ini termasuk dalam bidang perilaku keuangan (behavior finance).

Perilaku keuangan (behavior finance) sangat berperan dalam menjelaskan perilaku investor dan pengaruhnya terhadap pengambilan keputusan investasi. Penelitian yang menjelaskan perilaku investor individu pertama kali muncul sekitar tahun 1970-an. Behavior finance menyelidiki proses pengambilan keputusan yang berhubungan dengan pembelian atau penjualan aset keuangan dan memberikan alasan rasional di balik proses pengambilan keputuasan.Teori yang mendefinisikan perilaku keuangan pertamakali disampaikan oleh Kahneman danTyevsky (1979); dan Kahneman (1982). Khneman dan Tyevsky (1979) yang menyatakan bahwa investor tidak selalu tampak rasional untuk investasi seperti yang diharapkan. Perilaku ini menggambarkan bagaimana investor berprilaku tidak rasional dalam membuat keputusan investasi.

Perilaku keuangan adalah sebuah konsep baru yang telah menantang banyak kepercayaan lama tentang keuangan tradisional. Shefrin (1999) mendefinisikan perilaku keuangan sebagai "daerah yang berkembang pesat yang berkontraksi dengan pengaruh "psikologi tentang perilaku keuangan profesional". Menurut (Glaser et al 2004, p. 527) : "Perilaku keuangan sebagai subdisiplin dari ekonomi perilaku adalah keuangan yang menggabungkan temuan dari psikologi dan sosiologi ke dalam teorinya. Model perilaku keuangan selalu dikembangkan untuk menjelaskan perilaku investor atau anomali pasar ketika model rasional tidak memberikan penjelasan yang cukup ".

Salah satu karakter dari investor individu adalah terlalu percaya diri atau overconfidence. Karakter ini merupakan suatu kecenderungan berlebihan atas keyakinan maupun prediksi keberhasilan. Pengalaman individu dapat berupa keberhasilan 
memperoleh keuntungan atas investasi yang dijual kembali dengan harga yang melampaui harga belinya, hal ini kemudian memicu meningkatnya tingkat kepercayaan yang berlebihan (overconfidence). Perilaku ini muncul akibat orang melihat hal buruk yang menimpanya disebabkan faktor yang terjadi diluar kendalinya, akan tetapi apabila hal baik yang didapatkannya dianggap sebagai hasil dari sesuatu yang bisa ia kendalikan (bias atribusi) hal seperti ini memungkinkan terjadinya penafsiran informasi secara berlebihan (Weinstein Neil D, 1980). Investor yang memiliki pengalaman mendapatkan gain dari suatu investasi saham dapat meningkatkan kepercayaan dirinya (Van den Steen, 2004). Sebuah penelitian yang dilakukan oleh (Pavlevi dan oktaviani 2018) menghasilkan kesimpulan bahwa overconfidence memberi pengaruh yang positif terhadap perilaku investor individu. Analisis fundamental merupakan analisis yang digunakan mayoritas masyarakat dalam berinvestasi di bursa efek, begitupula dengan analisis tehnikal, penggunaan referensi, pengalaman, bahkan spekulasi pun digunakan dalam penentuan keputusan berinvestasi. Perilaku terlalu percaya diri dianggap menjadi sesuatu yang negatif dalam berinvestasi.

Perilaku lain yang umum dilakukan investor dalam melakukan investasi adalah perilaku herd yaitu suatu tindakan yang mengikuti perilaku dari mayoritas orang walaupun informasi yang diterima merupakan hal yang berbeda dari yang dilakukan kebanyakan orang (Banerjee, 1992). Penelitian juga dilakukan atas pengaruh perilaku herd dan umpan balik positif dalam mendestabilisasi harga saham (Chan et al., 1990). Menurut peneliti, perilaku herd mengacu pada kegiatan yang dilakukan oleh para manajer investasi, namun demikian, dalam perdagangan saham, umpan balik yang positif itu berasal dari kegiatan investor yang mendapatkan keuntungan dari pembelian saham dari investor individu yang mengalami kerugian akibat penjualan sahamnya. Pada penelitian yang lain dinyatakan pula bahwa perilaku herd dapat memberi pengaruh terhadap keputusan investasi di pasar saham. (Pavlevi dan oktaviani 2018) dalam penelitiannya mendapatkan hasil bahwa perilaku herd memberikan pengaruh positif pada perilaku investor.

Hasil penelitian yang dilakukan (Sumarni et al., 2012) menyatakan bahwa sifat dari investor individu di Indonesia adalah irasional dalam berinvestasi, mereka terdiri dalam dua kelompok besar. Kelompok confident big trader adalah kelompok yang mempunyai rasa kepercayaan diri yang tinggi serta kontrol yang tinggi, begitupula dengan nilai portfolio yang besar. Adapun kelompok kedua adalah loss averse small trader. Kelompok ini mempunyai rasa kepercayaan diri yang tinggi serta kontrol yang tinggi, namun nilai portfolio yang kecil.

Pada dasarnya pengambilan keputusan oleh individu maupun organisasi terbagi atas tiga model, yaitu rational decision-making, bounded rationality, dan intuition (Robbins dan Judge, 2013). Rational decision making model, model ini mendeskripsikan cara individu dalam berperilaku sehingga dapat memaksimalkan outcome. Model ini berasumsi bahwa pembuat keputusan memiliki informasi yang lengkap, mempunyai kemampuan mengidentifikasi semua opsi yang bermakna tanpa bias, dan memilih pilihan yang memberikan utilitas tertinggi.

Penelitian kualitatif (post positivisme) tentang perilaku investor diperlukan karena selama ini penelitian tersebut lebih banyak dilakukan dalam bentuk kuantitatif (perspektif paradigma positivisme) dengan menggunakan model matematik dan analisa statistik dengan landasan berpikir objektivitas. Padahal penelitian yang dilakukan pada suatu bidang ilmu tidak semata-mata terfokus pada alat analisis matematik dan statistik yang 
rumit tetapi lebih kepada landasan filsafat yang melatarbelakangi penelitian itu dilakukan (Chariri, 2009). Penelitian tentang perilaku manusia tidak harus mengacu pada makna dan tujuan yang ditempelkan oleh pelaku-pelaku manusia pada berbagai aktivitas mereka. Data dalam penelitian kualitatif diyakini dapat memberikan pengertian yang mendalam tentang perilaku manusia (Guba dan Linconl,1994 dalam Denzin dan Linconl, 2009).

Penelitian ini termasuk dalam jenis penelitian kualitatif dengan pendekatan fenomenologi dan dibawah paradigma interpretif. Jadi penelitian ini tidak bertujuan untuk memprediksi (to predict) atau untuk menjelaskan (to explain), tetapi untuk memahami (to understand) secara mendalam dari objek penelitian.

\section{METODE PENELITIAN}

Penelitian ini merupakan penelitian kualitatif dengan pendekatan fenomenologi menggunakan paradigma interpretif. Metode fenomenologi yang dipakai adalah fenomenogi dari Schutz, yaitu suatu metode fenomenologi yang digunakan untuk memaknai perilaku investor berdasarkan motif yang ada pada mereka.

Objek penelitian dalam penelitian ini ada 4 orang investor (Bapak UB, Bapak WR, Bapak SH, Bapak IB) yang berasal dari latar belakang yang berbeda. Nama sengaja disamarkan untuk menjaga privasi informan. Pemilihan informan ini dilakukan secara sengaja berdasarkan kriteria yang ditetapkan penulis antara lain: (a) investor individu harus terdaftar di Bursa Efek Indonesia (BEI); (b) investor aktif trading dengan tujuan jangka pendek maupun jangka panjang; (c) sudah berinvestasi di BEI kurang dari satu tahun; (d) Sudah pernah menghasilkan keuntungan (return) dari kenaikan modal (capital gain); (e) Sudah pernah merasakan kerugian.

Data yang digunakan dalam penelitian ini adalah data subjek yang melingkupi opini, sikap, pengalaman, atau karakteristik dari para informan yang berasal dari praktisi terkait. Data dan informasi didapatkan melalui wawancara informal, yang mana wawancara ini haruslah dilakukan secara spontan kepada terwawancara. Untuk menghindari para informan sudah menyediakan jawaban dan informasi terlebih dahulu maka pelaksanaan wawancara bersifat tidak terstruktur dan tidak terjadwal. Dengan demikian jawaban yang diberikan informan adalah jawaban apa adanya.

Tehnik analisis data yang digunakan dalam penelitian ini mengadopsi analisis data fenomenologi dari van Kaam dan Stevick, Collaizi, dan Kent Moustakas (Kent Moustakas: 1994). Peneliti membuat urutan rancangan analisis untuk mempermudah pengolahan data yang diperoleh yaitu mengindentifikasi unit makna, 9- identifikasi tematema lintas seluruh partisipan, dan identifikasi esensi pengalaman.

Dalam mengidentifikasi unit makna peneliti melakukan reduksi fenomenologi, dengan kegiatan: (1) transcribing, yaitu dengan mendengarkan kembali rekaman wawancara dan membuat transkrip hasil wawancara, (2) Indentifikasi unit makna dan menentukan tema, yaitu dengan mempertimbangkan setiap pernyataan informan dan mengeskstrak kedalam tema-tema serta pemberian label yang sesuai. Berikutnya adalah individual textual-structural description, yaitu tahap diskripsi tekstual yang diawali dengan validitas internal yaitu tiriangulasi. Triangulasi data antar waktu dilakukan pada masing-masing informan untuk mendapatkan konsistensi jawaban yang diberikan informan serta membandingkan konsistensi jawaban informan dari waktu ke waktu serta juga menyimpulkan tema tersebut. Tahap selanjutnya adalah identifikasi tema-tema lintas seluruh partisipan. Pada tahap ini dilakukan analisis silang untuk unit makna yang sama diantara partisipan dan membuat deskripsi tektual dan struktural untuk semua partisipan 


\section{AkMen

agar menemukan esensi makna dan membentuk matriks. Dan yang terakhir adalah identifikasi esensi pengalaman. Pada tahapan ini peneliti membuat refleksi dari pandangan dan pengalaman informan dengan cara menulis menggunakan bahasa penelitian yang harus merefleksikan konteks munculnya tema. Selanjutnya peneliti menstransformasikan ekspresi partisipan ke dalam bahasa yang sesuai dengan keilmuan yang mendukung riset. Keterkaitan tema-tema tersebut dijelaskan dalam suatu model untuk mempermudah pemahaman. Selain itu, pada tahap ini proposisi penelitian telah dapat diturunkan berdasarkan esensi makna pengalaman. Pengkonstruksian model ini diharapkan dapat menjadi suatu contoh peran, pemahaman dan strategi berinvestasi di pasar modal.

\section{HASIL DAN PEMBAHASAN}

\section{Hasil}

\section{Alasan Berinvestasi Saham}

Berikut ini hasil wawancara mendalam pada beberapa informan berkaitan dengan alasan berinvestasi saham. Informan pertama, Bapak WR menyampaikan bahwa awalnya karena penasaran setelah mencoba ternyata menghsilkan juga. Apalagi bunga bank sangat rendah dan lebih rendah dari inflasi. Dengan invesasi saham pendapatan saya akan meningkat.

"Saya melakukan investasi saham karena saya tidak puas dengan bunga bank deposito... bungannya kecil belum lagi inflasi... Awalnya coba-coba hehe ternyata dapat menambah penghasilan saya.. Saya kemudian mempelajari cara-caranya..yaa dari berbagai sumber lah..bisa internet, tv atau koran.."

Informan selanjutnya adalah SH karyawan swasta menyatakan ketertarikannya di dunia investasi saham dimulai dari keinginan sendiri dan banyak membaca referensireferensi bagaimana cara trading yang benar, seperti penyampaiannya sebagai berikut:

"Awalnya karena tertarik membaca bukunya Robert T. Kiyosaki yang membahas tentang Cash Flow Kuadran...dari buku itu saya menarik kesimpulan kita dapat mengelola uang sendiri tanpa bergantung pada orang lain...dari situ kemudian saya mulai main saham"

Berikutnya adalah Informan IB mahasiswa berumur 23 tahun, yang menyatakan alasannya berinvestasi saham karena returnnya lebih tinggi dan lebih likuid dibanding investasi lain, seperti pernyataan berikut:

"Jadi begini...e.e.e...dari yang saya pelajari saham itu mempunyai tingkat likuiditas yang tinggi dan memberikan tingkat pengembalian yang lebih tinggi dari deposito...nah makanya saya pilih main saham...untungnya besar soalnya..."

Informan terakhir adalah UB yang merupakan seorang pengusaha. UB menyapaikan alasanya menjadi investor karena risikonya lebih kecil dibandingkan berinvestasi di perkebunan. Menurutnya investasi saham lebih simpel karena dapat dilakukan secara online. Sekarang semua sudah online...kalau dulu repot harus telpon broker, sekarang online, seperti peryataannya berikut ini:

"Investasi saham itu resikonya kecil.... kalau dibandingkan misalnya investasi di perkebunan resikonya lebih besar karena ada faktor x nya,..bermain saham mudah dan simpel karena online....kalau dulu repot telpon broker kan, sekarang udah online."

\section{Investor Menurut Jangka Waktu Melakukan Perdagangan Saham}


Pada bagian pertaanyaan ini peneliti membagi informan menjadi 3 karakter unit berdasarkan perilaku trading mereka

\section{Day Trader}

SH termasuk investor day trader. Ia dapat bertransaksi jual beli berkali kali dalam sehari, mengambil keuntungan dari fluktuasi harga saham harian. Sama yang dilakukan istrinya yang ternyata juga seorang trader. Sebagai day trader $\mathrm{SH}$ biasa membuka beberapa posisi dalam hitungan menit per menit atau jam pertrading. SH sering melakukan pembelian di pagi hari kemudian menjual di sore hari. Sifat trader seperti SH ini sangat spekulatif dan tujuan investasinya adalah mendapat capital gain dari transaksi. Begini penuturannya ketika saya tanyakan mengapa memilih investasi saham:

“...Saya sudah belajar investasi sejak kuliah..tapi saya tidak tau prakteknya..tapi tau ada capital dan deviden...Investasi saham bagi saya adalah bisnis... Beli pagi beberapa menit kemudian kalau sudah untung langsung saya jual hehehe..biasanya dua kali dalam sehari saya masuk ke market"

Informan yang juga termasuk kategori day trader investor adalah WR yang berkerja sebagai pegawai swasta. WR awalnya terjun berinvestasi saham karena info dan ajakan dari teman, pertama WR ikut ikutan dengan temannya tapi setelah melakukan satu dua kali transaksi dia merasa kok menarik ya. Menurut penuturannya bahwa dia menggunaka jangka waktu saham kebanyakan adalah harian, seperti pernyataanya berikut ini.

"Pertama sih hanya ikut ikutan teman... begitu saya jalani ternyata jadi tertarik... kalau mau main yang penting itu harus mendalami, satu lagi yang mendasari juga karena ada fatwa MUI saham itu halal. Mungkin kalau tidak ada fatwa itu saya juga tidak mau ikut. Dalam berinvestasi hal yang penting itu harus antisipasi dan disiplin...saya kebanyakan transksi harian. Juga ada transaksi yang tidak selalu mulus..kan namanya juga trading tidak selamanya untung."

\section{Swing Trader}

IB tergolong investor swing trader. Investor ini mempunyai gaya trading dalam jangka waktu lebih lama dari investor day trader. Sebagai investor penganut swing trader IB mengharapkan keuntungan dari fluktuasi atau swing harga saham dalam waktu yang lebih panjang. Range time yang digunakan IB dari mulai beli kemudian dijual kembali biasanya berdasarkan hitungan hari hingga beberapa minggu. Hasil dari trading yang dilakukan IB digunakan untuk membayar uang kuliah dan saving seperti yang diungkapkannya:

“...Hasil trading saya simpan di dua rekening tabungan yang berbeda...jadi ada uang khusus saya sisihkan untuk trading harian atau mingguan...ada juga sih untuk jangka Panjang... Sebenarnya saya investor jangka panjang tetapi saya trading harian sama mingguan, lebih seringnya sih mingguan....hasil dari trading saya sisihkan khusus untuk bayar kuliah.."

\section{Position Trader}

Bapak UB adalah investor position trader. Dia membeli saham dalam periode yang lebih panjang dari daily trader dan swing trader. Transaksi yang dilakukan bisa dalam jangka waktu mingguan hingga bulanan. Karena itulah disebut position trader investor yang adalah trader yang melakukan trading yang lebih panjang dari swing trader. Pembelian atau penjualan saham pada investor position trader berada dalam jangka 
waktu minggu-an sampai hingga dua atau tiga bulan. Bapak UB sudah cukup lama bermain saham, begini penuturannya.

“....Sebelum melakukan pembelian saham saya tentukan posisi dulu...mau nyimpan mingguan atau bulanan...kadang saya sudah tentukan akan dijual setelah beberapa bulan eeehh ternyata sudah ada kenaikannya...langsung saya jual...walaupun kenaikannya tidak terlalu tinggi. Saya melihat dulu fundamental perusahaan sekalian juga melakukan analisis teknikal..baru kemudian membuat keputusan".

\section{Persiapan Sebelum Terjun ke Pasar Modal}

Dari keempat investor yang ada semua sepakat menyatakan bahwa persiapan, pengetahuan, kesabaran, dan mental sangat penting bila akan melakukan trading saham. Menurut Bapak WR:

"Kalau mau main saham harus punya ilmunya...tau kondisi ekonomi dan yang paling penting mental itu harus dijaga..saya mengecek info-info kadang dari internet, televisi...majalah sama koran ekonomi juga ada informasi sahamnya..."

Informan SH, menyatakan bahwa:

"Yang perlu dipersiapkan adalah mental...jangan sampai stress..biasa karena gugup kita jadinya buat keputusan yang salah..jadi main saham itu tidak boleh main-main...ini persoalan serius lho..makanya bermain saham itu harus punya ilmunya dan harus punya tujuan...ya begitu lah kira-kira.."

\section{Informan IB, menyatakan bahwa:}

"Saya hitungannya konsisten begitu dapat sedikit saya lepas. Saya tidak serakah harus balik modal 2 x saya tidak gitu, kalau $10 \%$ naik ... saya lebih yang penting konsisten. Mental juga sangat perlu harus siap, mental harus siap...harus tahu apa yang kita beli. Prinsipnya saya tidak serakah tapi tetap perhitungan, kalau saya ragu saya cari informasi dulu tentang history saham itu.

\section{Pembahasan}

Menurut hasil analisa, diantara keempat informan/investor/trader dalam penelitian ini, maka untuk pengamatan mengenai kepribadian kelompok investor sebagaimana telah dijelaskan sebelumnya, maka peneliti menggunakan Model Klasifikasi dari The Bailard, Biehl and Kaiser Model (BB\&K) yang mengklasifikasikan personaliti investor kedalam dua sumbu, yaitu level of convidence dan method of action

\section{Gambar 1. Model Klasifikasi dari The Bailard, Biehl and Kaiser (BB\&K)}

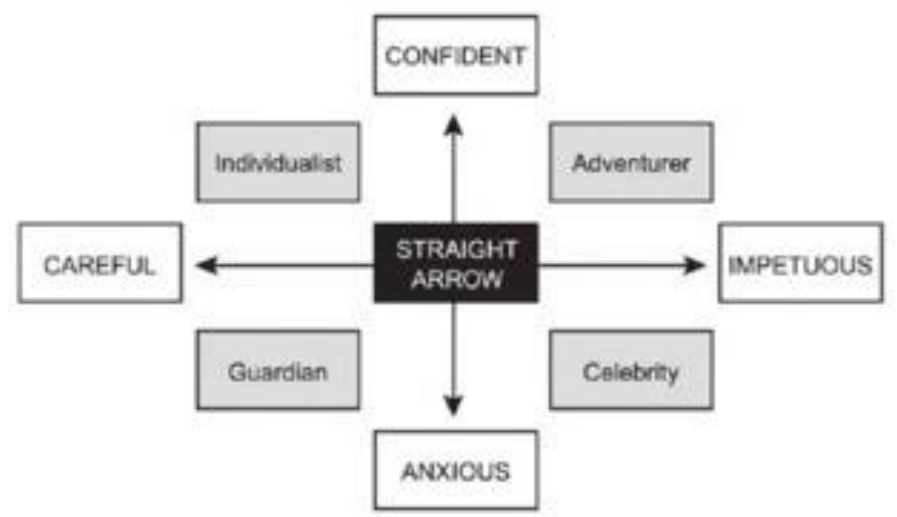


WR merupakan investor bertipe individualist, karena karakternya yang cenderung memiliki cara tersendiri dalam melakukan analisis investasi. Pemilihan saham yang akan dibeli dilakukan dengan analisis yang cermat dan teliti. Dengan perencanaan yang baik termasuk dalam keputusan penjualan saham sehingga keputusan yang diambil lebih dominan pertimbangan rasionalitasnya sendiri, meskipun informasi pihak lain banyak, dia tidak memperhatikan hal tersebut. Meskipun itu rekomendasi dari pialang dia sendiri.

SH dan IB merupakan investor bertipe the adventure, yaitu seorang investor yang lebih menyukai risiko, keputusan investasi sering berdasarkan berita atau momentum yang dianggap "hot", seperti rumor. Mereka ini memiliki issu sendiri yang kadang ide trading itu merupakan tantangan bagi kebanyakan investor lain. Investor ini memiliki kepercayaan diri yang cukup tinggi.

UB adalah tipe investor the guardian, karena berkarakteristik memiliki perilaku yang jangka panjang dan berhati-hati dalam investasi dan tidak terpengaruh rumor serta punya rencana investasi yang baik yang telah disettingnya. Mereka ini mengandalkan perpaduan pengetahuan dan emosi dalam investsi dan tidak mengutamakan percaya diri yang berlebihan, tapi percaya diri yang terukur dalam transaksi. Dalam setiap pengambilan keputusan selalu meminta dan mendengarkan serta mempertimbangkan pendapat dari broker, atau sumber informasi yang valid lainnya. Investor ini tidak terlalu menyukai volatilitas karena mereka berinvestasi dalam jangka panjang, buka harian dan bulanan.

Sedangkan tipe investor celebrity tidak bisa digolongkan dalam penelitian ini karena semua investor memiliki karakteristik yang tidak termasuk tipe celebrity ini. Dengan demikian, keempat investor itu tidak ada satu seorangpun yang cukup tepat dan bisa dikategorikan sebagai investor bertipe celebrity. Karena ciri-ciri investor bertipe celebrity adalah dia tidak punya ide dalam transaksi sedangka dalam penelitian ini semua investor memiliki ide dalam transaksi masing-masing mareka. Pengambilan keputusan investasi hanya untuk ditampilkan saja supaya teman-temannya atau orang lain memandang dia tenar atau hebat dalama membeli saham, dan umumya mereka bertransaksi saham agar bisa dilihat orang lain atau membuat orang lain kagum padanya.

\section{KESIMPULAN}

Perilaku investor dalam mengambil keputusan investasi mencerminkan sejauh mana nilai-nilai dari prinsip investasi yang mareka resapi dan pahami sehingga apa yang mereka lakukan selalu dilandasi alasan yang jelas, baik karena pengalaman, kekinian maupun tujuan masa depan. Lebih lanjut, ditemukan juga tiga tipe trader (investor jangka pendek ) yaitu day trader, swing trader, dan position trader.

Pengetahuan yang baik tentang investasi dan pengendalian emosi serta belajar dari pengalamaan merupakan faktor-faktor yang menentukan perilaku investor dalam transaksi saham. Memahami investasi dan mekanisme perdagangan serta terus belajar dari sumber manapun merupakan modal dasar yang permanen yang perlu dimiliki investor disamping terus mengamati dan menyikapi isu-isu ekonomi yang berkembang. Dililhat dari lima kelompok kepribadian investor maka urutan kelompok kepribadian investor terdiri dari individualist, adventure dan guardian, sedangkan kelompok perilaku celebrity tidak ditemukan.

\section{SARAN}


Penelitian ini memberikan implikasi teoritis bahwa pemahaman psikologis investor akan memperkecil penyimpangan perilaku irrasional investor di pasar modal sebagaimana dibicarakan dalam teori perilaku keuangan bahwa unsur perilaku turut menentukan kepanikan pasar saham. Demikian juga dalam praktek investasi dan teori berjalan seiring dimana mareka harus dipadukan dalam pengambilan keputusan investasi. Dengan demiikian keduanya saling melengkapi agar keputusan investasi lebih lebih tepat.

Bagi calon investor, penelitian ini dapat memberikan proses pembelajaran secara lebih tepat bila ingin terjun ke pasar modal mengenai apa saja yang perlu dipersiapkan. Oleh karena itu bagi investor perlu untuk menetapkan rencana perdagangan sebelum terjun ke pasar modal, dan perlu juga bagi regulator untuk mengoptimalkan sosialisasi dan edukasi saham ke masyarakat lebih intensif lagi.

Karena day trader merupakan tipe investor yang sangat rentang menghadapi risiko rugi maka bagi investor diharapkan sebelum memahami betul seluk beluk investasi harian agar mengurungkan niatnya untuk bermain sebagai day trader yang masuk kategori investor kontemporer, dimana pengetahuan, pengalaman dan pengendalian emosi merupakan aspek utama untuk sukses dalam transaksi saham.

Keterbatasan penelitian ini belum memasukkan investor individu wanita sebagai bagian dari penelitian. Padahal investor wanita secara perilaku tentu akan menggunakan perasaanya dalam penentuan keputusan investasinya. Penelitian selanjutnya tentu akan menarik dan melengkapi kekurangan dari penelitian ini. Pemilihan investor wanita tentu akan memberikan hasil dengan warna yang berbeda dengan investor pria.

\section{DAFTAR PUSTAKA}

Bayu Aprillianto, N. W. (2014). Perilaku Investor Saham Individual Dalam Pengambilan Keputusan Investasi: Studi Hermeneutika-Kritis. e-Journal Ekonomi Bisnis dan akuntansi, 1, 16-31.

Banerjee, A. (19912). A Simpel Model Of Heed Behavior. Quarterly Journal Of Economics, 107(3), 737-817.

Creswell, J. (2007). Qualitative Inquary and Research Design, Choosing Among Five Approaches. Sage Publication.

Chariri, A. (n.d.). Landasan Filsafat dan Metode Penelitian Kualitatif. Semarang: Paper Diasajikan pada Workshop Metodologi Penelitian Kuantitatif dan Kualitatif, LPA, Fakultas Ekonomi, Undip Semarang.

Chan, L. H. (1990). Fundamental and Stock Return in Japan Working Paper No 45 Working Paper Series Center on Japanese Economy and Business Graduate School of Business Columbia Uniersity.

Chandra, Rudy. 2010. Analisis Pemilihan Saham oleh Investor Asing di Bursa Efek Indonesia. Jurnal Ilmu Administrasi dan OrganisasiVolume 17, Nomor 2 ISSN 0854-3844

Denzin, N. K. (2009). Handbook of Qualitative Research. Terjemahan. Pustaka Pelajar. 
Fama, Eugene F. (May 1970), "Efficient market: A review of theory and empirical work", Journal of Finance, 25 (2): 383-417.

Fatchan, A. (2011). Metode Penelitian Kualitatif, Beserta Contoh Soal Proposal Skripsi, Tesis, dan Disertasi. Surabaya: Jenggala Pustaka Utama.

Glaser, M. N. (2004). Behavioral finance”, in Koehler, D.J. and Harvey, N. (Eds), Blackwell Handbook of Judgment and Decision Making. Oxford.

https://investasi.kontan.co.id/news/terdorong-domestik-retail-jumlah-investor-pasarmodal-tembus-44-juta diakses pada tanggal 29 Mei 2021

Johnson, J. G. (2005, September). Losers, Winners, and Biased Trades. Journal of Consumer Research.

Kahneman, D. a. ((1979)). Prospect Theory: An Analysis of Decision under Risk, Econometrica. .

Kahneman, D. a. (1982). John Wiley and Sons.

Linconl, Y. d. (1994). Competing Paradigm in Qualitative Research.

Natapura, Cecilia. 2009. Analisis Perilaku Investor Institusional dengan Pendekatan Analytical Hierarchy Process (PHP). Jakarta: Jurnal Ilmu Administrasi dan Organisasi Volume 16, Nomor 3 ISSN 0854-3844.

Robbins, S. P. (2013). Organizational Behavior. 15th ed. Pearson Education. .

Robbins, S. P. (2002). Essential of Organizational Behavior, Fifth Edition, Halida, Sartika. D., (Penerjemah). Prinsip-Prinsip Perilaku Organisasi. Jakarta.: Erlangga .

Scott, W. ( 2009). Financial Accounting Theory. 4th ed. Toronto: Pearson Education Canada Inc.

Shefrin, A. (1999). Inefficient Markets: An Introduction to Behavioral Finance. Oxford University Press.

Sumani, C. W. (2012). Perilaku Investor Di Pasar Modal Indonesia . Ekuitas: Jurnal Ekonomi dan Keuangan.

Van den Steen, E. A. (2004). Rational Overoptimism (and Other Biases. American Economic Review, 94(4 ), 1141-1151.

Wood, R. d. (2004). Attitudes and Trading Behavior of Stock Market Investors: A Segmentation Approah. The Journal of Behavioral Finance, 51(3), 170-179. 